\title{
Atmospheric deposition of mercury and major ions to the Pensacola (Florida) watershed: spatial, seasonal, and inter-annual variability
}

\author{
J. M. Caffrey ${ }^{1}$, W. M. Landing ${ }^{2}$, S. D. Nolek ${ }^{3}$, K. J. Gosnell ${ }^{4}$, S. S. Bagui ${ }^{5}$, and S. C. Bagui ${ }^{6}$ \\ ${ }^{1}$ Center for Environmental Diagnostics and Bioremediation, University of West Florida, 11000 University Parkway, \\ Pensacola, FL 32514, USA \\ ${ }^{2}$ Dept. of Oceanography, Florida State University, 1015 West Call Street, Tallahassee, FL 32306-4320, USA \\ ${ }^{3}$ PetroAlgae, 1901 S. Harbor City Blvd., Suite 300, Melbourne, FL 32901, USA \\ ${ }^{4}$ Dept. of Oceanography, Florida State University, 1015 West Call Street, Tallahassee, FL 32306-4320, USA \\ ${ }^{5}$ Dept. of Computer Science, University of West Florida, 11000 University Parkway, Pensacola, FL 32514, USA \\ ${ }^{6}$ Dept. of Mathematics and Statistics, University of West Florida, 11000 University Parkway, Pensacola, FL 32514, USA
}

Received: 24 November 2009 - Published in Atmos. Chem. Phys. Discuss.: 15 February 2010

Revised: 21 May 2010 - Accepted: 14 June 2010 - Published: 21 June 2010

\begin{abstract}
Atmospheric deposition was measured at three sites in the Pensacola Bay watershed, Florida, between November 2004 and December 2007. Mercury deposition in the Pensacola Bay watershed was similar to that from nearby Mercury Deposition Network sites along the Northern Gulf of Mexico coast. Mercury deposition during the summer months is higher than other months due to higher concentrations in rainfall throughout the region. Deposition of constituents like $\mathrm{H}^{+}$, sulfate, nitrate, ammonium, chloride and sodium, were much higher in Pensacola Bay that at National Atmospheric Deposition Program (NADP) sites. Chloride and sodium deposition are higher because Pensacola Bay sites are closer to the Gulf of Mexico which is a source of sea salt aerosols. Acid rain constituents, $\mathrm{H}^{+}$, sulfate, nitrate and ammonium are most likely higher at Pensacola Bay sites because these sites are much closer to emission sources of these constituents than NADP sites, particularly two Florida NADP sites, FL14 and FL23, which are located in rural counties far from major industrial activities.
\end{abstract}

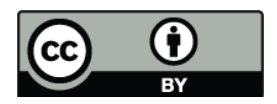

Correspondence to: J. M. Caffrey (jcaffrey@uwf.edu)

\section{Introduction}

Atmospheric concentrations of many compounds including nitrogen, mercury, copper, zinc, sulfur, and polyaromatic hydrocarbons have increased since the industrial revolution due to combustion of fossil fuels, industrial and manufacturing processes and agricultural operations. Mercury emissions to the atmosphere are primarily associated with coal burning power plants, industrial processes such as chlor-alkali production, and waste incinerators (Pirrone et al., 1996; Pacyna et al., 2005). Mercury in the atmosphere occurs in 3 different forms: elemental gaseous mercury $\left(\mathrm{Hg}^{0}\right)$, reactive gaseous mercury ( $\mathrm{RGM}$ or $\mathrm{Hg}^{2+}$ ) which is the oxidized form, and mercury associated with particles $(\mathrm{HgP})$. Reactive gaseous mercury is usually deposited near the source of the emission (Dvonch et al., 1998; Lin and Pehkonen, 1999), while elemental gaseous mercury has a residence time in the atmosphere of 1-2 yr, thus deposition may be worldwide (Lindqvist and Rodhe, 1985). Reactive gaseous mercury can be adsorbed directly onto plant and soil surfaces, as well as associated with soot, fog droplets or rain drops (Lin and Pehkonen, 1999).

Deposition of atmospheric constituents to land and water surfaces occurs at a wide range of scales, from less than a kilometer to hundreds of kilometers from the emission sources. Thus, airsheds encompass huge areas, usually 10 to 100 times greater than watershed area (Valigura, 2001).

Published by Copernicus Publications on behalf of the European Geosciences Union. 
Airshed boundaries are amorphous, dynamic and dependent on regional weather patterns. Atmospheric deposition represents a significant source of nitrogen and contaminants in many watersheds (Valigura, 2001). Between 50-90\% of the mercury load to US waters originates from atmospheric deposition (http://nadp.sws.uiuc.edu/). Deposition of these compounds onto land and water surfaces has a negative impact on plant and animal communities, ecosystem function and human health. Accumulation of toxic contaminants in animal tissues can lead to reproductive failures. Toxic compounds such as mercury, selenium and organic chemicals accumulate in food chains increasing human health risks when fish or waterfowl are consumed. Currently, 42 states have mercury consumption advisories for freshwater fish while the Southeast and Gulf coasts have coastal fish advisories (http://nadp.sws.uiuc.edu/).

The growth of monitoring networks (e.g. National Atmospheric Deposition Program (NADP)) since 1978 has provided an increasingly detailed picture on atmospheric deposition at the national and regional level in the United States. The National Atmospheric Deposition Program, which includes the Mercury Deposition Network (MDN), is a national network of collaborating state and federal agencies that collect data to examine long-term trends in atmospheric deposition at regional scales. Regional and national trends provide critical information necessary for determining policies to improve air and water quality at the national level (Lynch and Kerchner, 2004; Lindberg et al., 2007). However, in order to improve water quality at the watershed level, the importance of local sources in addition to regional sources needs to be determined. Urban areas frequently have higher mercury deposition than rural areas (Mason et al., 1997; Keeler and Dvonch, 2005; Keeler et al., 2006; Van Arsdale et al., 2007), particularly areas downwind of coal-fired utilities (White et al., 2009). In addition, sampling individual rain events provides a more detailed assessment of rain composition that can be used for source tracking.

Our primary objective was to measure mercury, trace metals and major ions in rainfall over annual cycles. We evaluated the temporal and spatial patterns in atmospheric deposition by comparing the results among 3 sites in the Pensacola Bay watershed and comparing them with data collected at MDN and NADP sites along the Central Gulf of Mexico coast. Our primary research question was what is the spatial distribution of mercury, trace metal and nutrient deposition in the Pensacola Bay watershed? Trace metal data are presented in Landing et al. (2010).

\section{Study area}

This research was conducted as part of the Partnership for Environmental Research and Community Health in order to understand the contribution of mercury and trace metals from atmospheric sources to the Pensacola Bay re- gion. Air quality in Pensacola Bay is affected by emissions from industrial sources, automobiles and other vehicles as well as other stationary area sources such as dry cleaners, gas stations, agriculture, and construction sites (FDEP, 1998). Industrial sources include a coal fired electric generating plant, a paper mill, chemical and other manufacturing companies. $\mathrm{NO}_{\mathrm{x}}$ and $\mathrm{SO}_{2}$ emissions are dominated by power generation, although automobile and other vehicles are also a large source of $\mathrm{NO}_{\mathrm{x}}$. The major source of mercury emissions in 2005 was from Plant Crist, the coalfired electric generating plant, which was estimated to release approximately $87 \mathrm{~kg}$ (EPA website: http://www.epa. gov/air/data/reports.html). Other mercury emission sources in the Pensacola Bay watershed include coal-fired industrial boilers at the International Paper Plant $(0.9 \mathrm{~kg})$, medical waste incineration $(0.0009 \mathrm{~kg})$ and landfills $(0.018 \mathrm{~kg})$ (T. Rogers, personal communication, 2009). Nearby Mobile and Escambia Counties in Alabama have significant sources of mercury emissions, approximately 350 and $400 \mathrm{~kg}$ respectively in 2002 (http://www.epa.gov/air/data/repsco. html?co 01053\%2001097 Escambia\%20Co\%2C\%

20Mobile\%20Co\%2C\%20Alabama).

\section{Methods}

Rain collectors were installed at 3 sites between November and December 2004 (Fig. 1) for event based collection of rain samples. Rain samples were collected within $24 \mathrm{~h}$ of $0.5 \mathrm{~cm}$ rain events using Aerochemetrics or Loda rain collection devices. Buckets were modified to hold 3 bottles with Teflon collars as in the Florida Atmospheric Mercury Study (Landing et al., 1995). Duplicate Teflon bottles for mercury and trace metal analysis were deployed along with a single polyethylene bottle for $\mathrm{pH}$ and major ions analysis. Approximately $10 \%$ of the deployments had a single Teflon bottle for mercury and trace metal samples and duplicate polyethylene bottles for $\mathrm{pH}$ and major ions. Trace metal results are reported in Landing et al. (2010). Sampling in 2005 was suspended for 2 weeks by Hurricane Dennis because collectors were removed from the sites to keep them from being damaged or destroyed.

\subsection{Mercury analysis}

Rain samples (in FEP Teflon bottles) were acidified after collection to $0.045 \mathrm{M} \mathrm{HCl}$ plus $0.048 \mathrm{M} \mathrm{HNO}_{3}$, then placed in a low wattage UV digestion box for at least $48 \mathrm{~h}$ to completely solubilize the collected Hg. The digested samples were analyzed by CVAFS using EPA method 1631 using a Tekran 2600 Mercury Analyzer at Florida State University. 


\subsection{Major ions and $\mathrm{pH}$}

The $\mathrm{pH}$ of the samples was measured in the laboratory immediately following collection. The major ions, nitrate $\left(\mathrm{NO}_{3}^{-}\right)$, ammonium $\left(\mathrm{NH}_{4}^{+}\right)$, phosphate $\left(\mathrm{PO}_{4}^{3-}\right)$, sulfate $\left(\mathrm{SO}_{4}^{2-}\right)$, sodium $\left(\mathrm{Na}^{+}\right)$, chloride $\left(\mathrm{Cl}^{-}\right)$, magnesium $\left(\mathrm{Mg}^{2+}\right)$, calcium $\left(\mathrm{Ca}^{2+}\right)$, and potassium $\left(\mathrm{K}^{+}\right)$were measured in polyethylene sample bottles. Major ion analyses were conducted using a Dionex DX500 ion chromatograph using EPA method 300.0 for anions and Dionex protocols (Application Note 141, http://www.dionex.com/en-us/ webdocs/4211-AN141_V15.pdf) for cations at the University of West Florida. Phosphate, magnesium, calcium and potassium were often below detection limits $\left(0.03 \mathrm{mg} / \mathrm{L} \mathrm{PO}_{4}^{3-}\right.$, $0.02 \mathrm{mg} / \mathrm{L} \mathrm{Mg}^{2+}, 0.04 \mathrm{mg} / \mathrm{L} \mathrm{Ca}^{2+}, 0.02 \mathrm{mg} / \mathrm{L} \mathrm{K}^{+}$), so values are not reported here.

\subsection{Calculations and statistics}

Deposition was calculated by multiplying the measured concentrations (grams per cubic meter) by the rainfall amounts (meters per event), and are expressed as mass per square meter (per event). We tested for differences between sites, seasons and years using an Analysis of variation (ANOVA). The seasons are winter (December, January, February), spring (March, April, May), summer (June, July, August) and fall (September, October, November). We used the event based data to compare our three sites. A correlation analysis of mercury and major ion deposition was performed on the data. In addition, we compared our sites with Mercury Deposition Network (MDN) and National Atmospheric Deposition Program (NADP) sites in Northern Gulf of Mexico region (Fig. 1, NADP, 2009) using ANOVA to test for differences among sites. For this comparison, we summed our data over the same weekly intervals as the NADP and MDN sites. The level of significance equal or less than 0.05 was used for these analyses.

\section{Results}

Over the course of this study from 19 November 2004 through 2 January 2008, we collected 565 rain samples from 3 sites. These samples represent about 225 separate rain events in the Pensacola Bay watershed. The amount of precipitation was not significantly different among the 3 sites, nor were there any significant inter-annual differences. However, seasonal differences were significant with the higher volume rainfall events in the spring and fall and the lower volume rainfall during winter. Approximately $33 \%$ of the total rainfall occurs in the summer, $28 \%$ in the fall, $23 \%$ in the spring and only $16 \%$ in the winter.

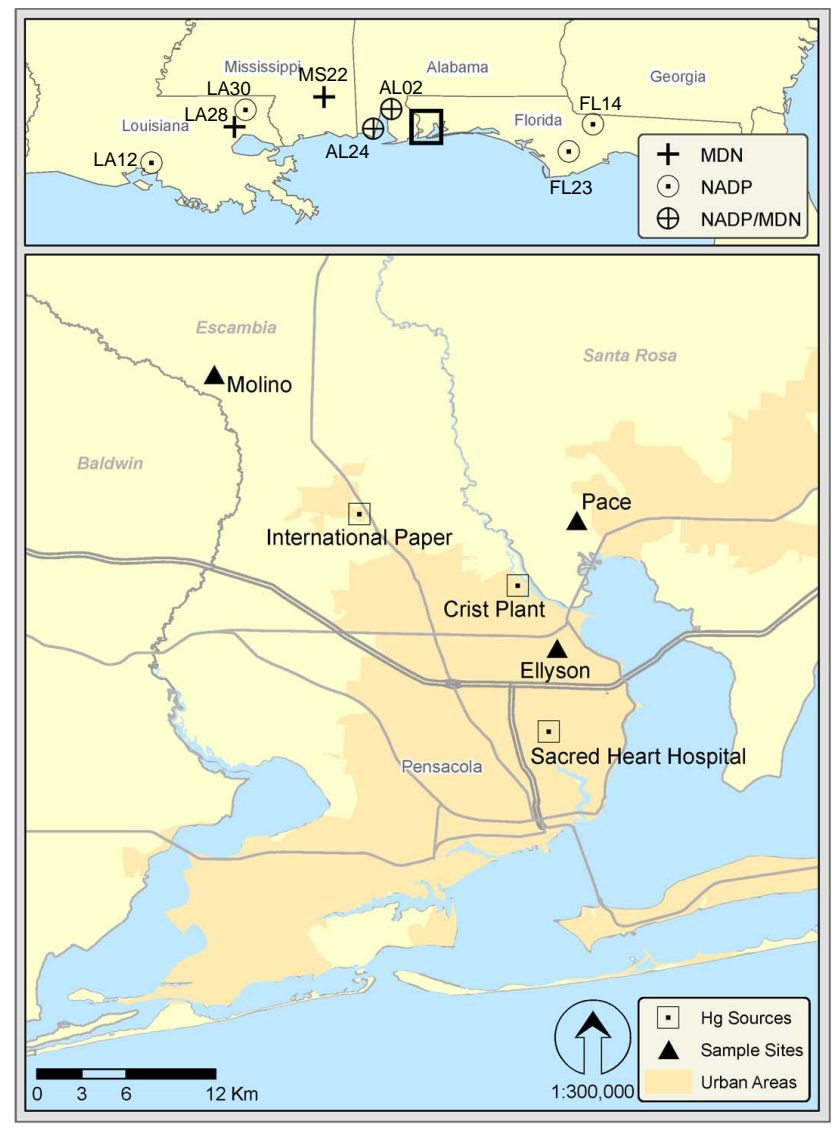

Fig. 1. Map of Pensacola Bay showing sampling locations: Ellyson, Molino and Pace. Mercury emission sources: Crist Plant, International Paper, Sacred Heart Hospital medical waste incinerator. Inset map shows location of Mercury Deposition Network (MDN) and National Atmospheric Deposition Program (NADP) sampling sites along the central Gulf Coast.

\subsection{Mercury concentrations in rainfall}

The concentration of mercury was significantly higher in low volume samples (Fig. 2). With larger storms, mercury concentrations were diluted $\left(R^{2}=0.26, p<0.001\right)$. A similar pattern was observed for sulfate and ammonium, while $\mathrm{pH}$ values were generally more variable in low volume samples, with many samples less than 4 or greater than 5.5 (data not shown). Mercury deposition showed no site differences between the three Pensacola Bay watershed sites (Fig. 3). Mercury deposition from individual events ranged between 13 and $2050 \mathrm{ng} / \mathrm{m}^{2} /$ event. There were significant seasonal differences. The highest mercury deposition occurred in the summer $\left(403 \pm 19.9 \mathrm{ng} / \mathrm{m}^{2} /\right.$ event $)$ compared to other seasons (fall $286 \pm 18 \mathrm{ng} / \mathrm{m}^{2} / \mathrm{event}$, winter $245 \pm 15 \mathrm{ng} / \mathrm{m}^{2} /$ event, spring $333 \pm 24 \mathrm{ng} / \mathrm{m}^{2} /$ event). Interannual differences were significant with the highest average deposition in $2007\left(400.7 \mathrm{ng} / \mathrm{m}^{2} /\right.$ event $)$ and the lowest in 2006 (286 ng/m²/event). 


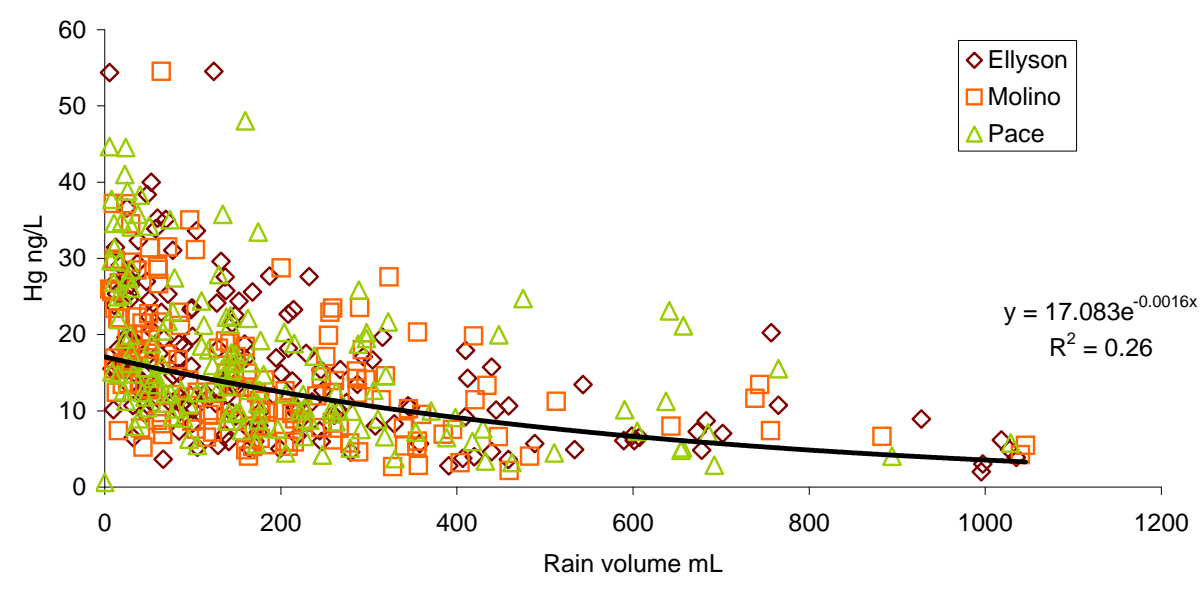

Fig. 2. Mercury $(\mathrm{Hg} \mathrm{ng} / \mathrm{L})$ concentration versus the volume of rain $(\mathrm{mL})$ collected in sample bottles at Pensacola Bay sites.

\subsection{Precipitation chemistry}

For each of the major ion deposition $\left(\mathrm{H}^{+}\right.$, sulfate, nitrate, ammonium, chloride and sodium), we found no significant differences among the 3 Pensacola Bay sites. There were significant seasonal differences in $\mathrm{H}^{+}$, nitrate and ammonium deposition, but not sulfate, chloride or sodium deposition. The highest $\mathrm{H}^{+}$deposition occurred in summer and the lowest during winter and fall (Fig. 3). Nitrate deposition was also significantly lower during the winter $(16.5 \mathrm{mg}$ $\mathrm{NO}_{3} / \mathrm{m}^{2} /$ event $)$ and fall $\left(26.0 \mathrm{mg} \mathrm{NO} 3 / \mathrm{m}^{2} /\right.$ event $)$ compared to spring (56.4 $\mathrm{mg} \mathrm{NO} 3 / \mathrm{m}^{2} /$ event) and summer $(45.1 \mathrm{mg}$ $\mathrm{NO}_{3} / \mathrm{m}^{2} /$ event) (Fig. 4). The seasonal pattern in ammonium was the same as nitrate deposition with higher deposition in the spring $\left(9.2 \mathrm{mg} \mathrm{NH}_{4} / \mathrm{m}^{2} /\right.$ event) and summer $(5.2 \mathrm{mg}$ $\mathrm{NH}_{4} / \mathrm{m}^{2} /$ event) and lower deposition during the fall $(1.9 \mathrm{mg}$ $\mathrm{NH}_{4} / \mathrm{m}^{2} /$ event $)$ and winter ( $2.5 \mathrm{mg} \mathrm{NH}_{4} / \mathrm{m}^{2} /$ event) (Fig. 4).

The average sulfate deposition was $40.43 \mathrm{mg}$ $\mathrm{SO}_{4} / \mathrm{m}^{2} /$ event and values from individual rain events ranged from 0.5 to $438 \mathrm{mg} \mathrm{SO} 4 / \mathrm{m}^{2} /$ event (Fig. 3). The average nitrate deposition was 35.6 and values ranged from 0.5 to $285 \mathrm{mg} \mathrm{NO} / \mathrm{m}^{2} /$ event (Fig. 4). Nitrate deposition in 2007 (19.5 mg NO $3 / \mathrm{m}^{2} /$ event) was significantly lower than in $2005\left(45.5 \mathrm{mg} \mathrm{NO} / \mathrm{m}^{2} /\right.$ event $)$ or $2006(43.2 \mathrm{mg}$ $\mathrm{NO}_{3} / \mathrm{m}^{2} /$ event). Ammonium deposition was about 30 percent of the nitrogen deposition (Fig. 4). Average ammonium deposition was 4.35 and values ranged from 0.04 to $46.3 \mathrm{mg}$ $\mathrm{NH}_{4} / \mathrm{m}^{2} /$ event.

Chloride deposition had a larger range than the other major element deposition, with a few deposition exceeding $1000 \mathrm{mg} / \mathrm{m}^{2} /$ event, particularly at Ellyson (Fig. 5). This is likely due to the accumulation of sea salt aerosols in rainwater. The average chloride deposition was 58.76 and values ranged from 0.6 to $2.070 \mathrm{mg} / \mathrm{m}^{2} /$ event. There were no significant differences in chloride deposition among the different sites, years or seasons. Sodium deposition also had a large range and generally tracked the chloride concentrations
(Fig. 5). As observed with the chloride deposition, sodium deposition had no significant differences among the different sites, years or seasons. Average sodium deposition was 24.5 and values ranged from 0.2 to $938 \mathrm{mg} / \mathrm{m}^{2} /$ event.

\subsection{Comparisons with MDN and NADP sites}

Mercury deposition along the Northern Gulf of Mexico was similar among MDN and Pensacola Bay sites. There were no interannual differences in mercury deposition, although seasonal deposition rates were significantly different from one another. As we observed with the Pensacola Bay data alone, summer deposition was significantly higher than deposition during the other months. Summer mercury deposition represented an average of $44 \%$ of the total annual mercury deposition at these sites and could represent as much as $60 \%$ for some sites in some years.

Sites in Pensacola Bay area were often higher than NADP sites for $\mathrm{H}^{+}$, sulfate, nitrate, ammonium, chloride, and sodium deposition. $\mathrm{H}^{+}$deposition at Ellyson and Pace were significantly higher than at all other NADP sites, while deposition at Molino was significantly higher than FL14 and LA30. Sulfate deposition at Ellyson was significantly higher than all NADP sites; Pace was significantly higher than NADP sites in Florida and Louisiana, while Molino was significantly higher than the NADP sites in Florida. Nitrate deposition at all Pensacola Bay sites was significantly greater than NADP sites. Ammonium deposition at Ellyson was greater than FL14 and FL23. Ammonium deposition at the NADP site LA30 was also greater than those at FL23. Chloride deposition at Ellyson were greater than those at Molino and all NADP sites, while Pace was greater than the NADP sites in Florida, Louisiana and at AL02. Sodium deposition was significantly higher at Ellyson than at all NADP sites. Pace also had significantly higher sodium deposition than at all NADP sites except for AL24. 

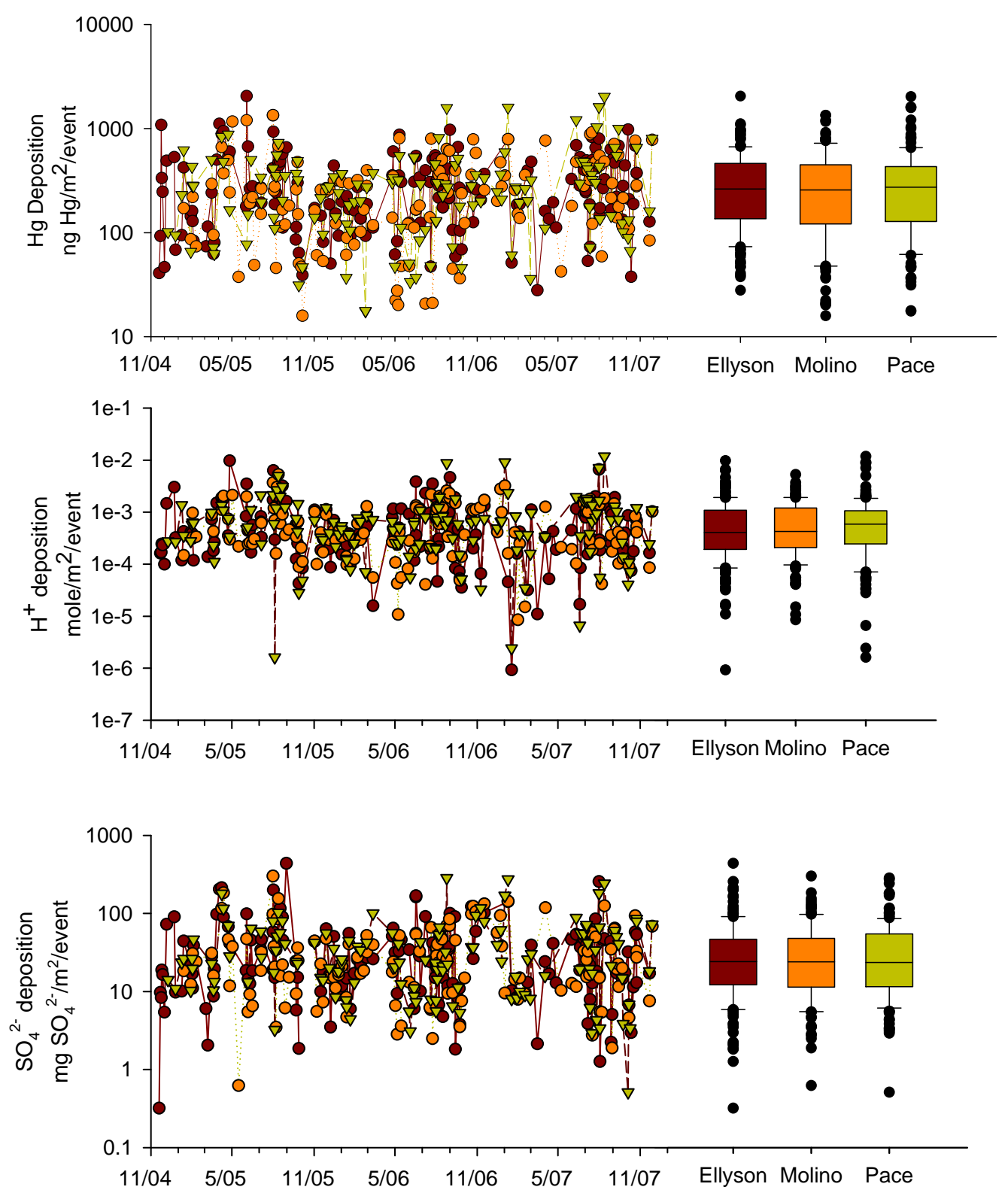

Fig. 3. Mercury ( $\mathrm{Hg}$ ) deposition (ng/m²/event) (top panel), $\mathrm{H}^{+}$deposition (mole $/ \mathrm{m}^{2} /$ event) (middle panel), and sulfate ( $\mathrm{SO}{ }_{4}^{2-}$ ) deposition (bottom panel) ( $\mathrm{mg} \mathrm{SO}_{4} / \mathrm{m}^{2} /$ event) at Ellyson (brown), Molino (orange) and Pace (green) between November 2004 and December 2007 for individual rain events (left side). Box plot (right side) for each site, showing median, 25th and 75th percentiles (box boundary), 10th and 90th percentiles (whiskers), and outliers (circles).

There were significant seasonal differences in sulfate, nitrate, ammonium and chloride deposition with sulfate, nitrate and ammonium having higher deposition in the spring and summer than the other seasons. Chloride deposition was highest in the fall. Inter-annual differences were significant for sulfate and nitrate deposition with higher deposition in 2005 and 2006 compared to $2007 . \mathrm{H}^{+}$and ammonium deposition declined over the three years of observations.

\section{Discussion}

These results have shown that there were no significant differences in mercury deposition among our three sampling sites or between our sites and MDN sites in the Northern Gulf of Mexico between 2005 and 2007. The mercury deposition at the Ellyson site, which is about $4.8 \mathrm{~km}$ away and generally downwind of the Crist coal fired power plant (Fig. 1), was not significantly higher than at the Molino site which is furthest away from local mercury emission sources $(24 \mathrm{~km}$ from Crist 

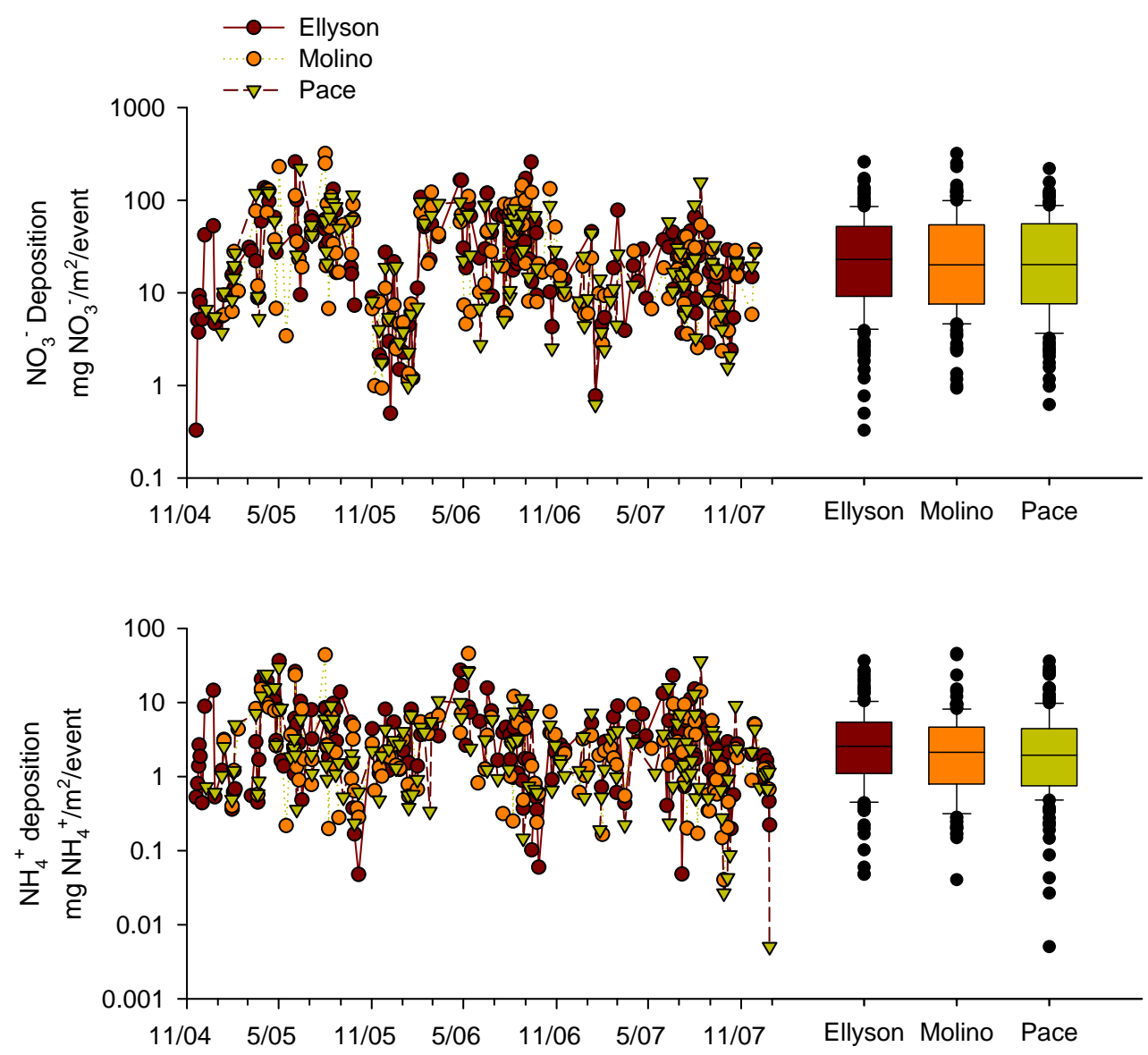

Fig. 4. Nitrate $\left(\mathrm{NO}_{3}^{-}\right)$deposition $\left(\mathrm{mg} \mathrm{NO}_{3} / \mathrm{m}^{2} /\right.$ event) (top panel) and ammonium $\left(\mathrm{NH}_{4}^{+}\right)$deposition $\left(\mathrm{mg} \mathrm{NH} / \mathrm{m}^{2} / \mathrm{event}\right)($ bottom panel) as in Fig. 3.

power plant and $14 \mathrm{~km}$ from International Paper). Our results contrast with studies in Michigan and Maryland which found higher mercury deposition in urban areas compared to rural areas (Mason et al., 2000; Lawson and Mason, 2001; Landis et al., 2002; Keeler and Dvonch, 2005) and those finding higher concentrations of mercury in rainwater close to coalfired utilities (White et al., 2009). We did observe seasonal differences, with the highest deposition rate during the summer at Pensacola Bay and MDN sites. Summer deposition at our sites and the nearby MDN sites represents about $43 \%$ of the total annual mercury deposition, similar to findings in Maryland (Mason et al., 2000) and throughout the Southeast (Butler et al., 2008). This contrasts with the FAMS study which found that summer deposition in south Florida was between $80-90 \%$ of total mercury deposition (Guentzel et al., 1995). Higher summer mercury deposition is not driven by higher rainfall amounts, but by higher concentrations in the rain since the highest rainfall amounts are usually in the spring and fall. Several mechanisms leading to enhanced mercury concentrations in rain during the summer include greater emissions associated with higher electricity use, scav- enging of reactive gaseous mercury from the free troposphere by tall convective thunderstorms, and the concentration of reactive gaseous mercury by the sea breeze effect, where the diurnal alternation of onshore and offshore winds can lead to a buildup of pollutants in the air mass. In the Pensacola Bay area, $\mathrm{SO}_{2}$ levels increased as the sea breeze move urban air masses offshore and then back onshore (Chang et al., 2007). Keeler and Dvonch (2005) also observed strong seasonal patterns in atmospheric mercury deposition in Michigan with higher deposition in the summer due to higher concentrations of mercury in rain droplets compared to ice crystals that form in winter. As with seasonal differences, inter-annual variability was not strictly driven by rainfall amount since the year with the highest rainfall, 2005, had an intermediate mercury deposition rate.

The deposition of major ions (sulfate, chloride, nitrate, sodium, $\mathrm{H}^{+}$, or ammonium) was similar among the Pensacola Bay sites and often significantly higher than NADP sites. The NADP sites in Florida (FL14 and FL23) often had the lowest values of all the sites examined. This is consistent with other studies that have shown higher deposition in urban 

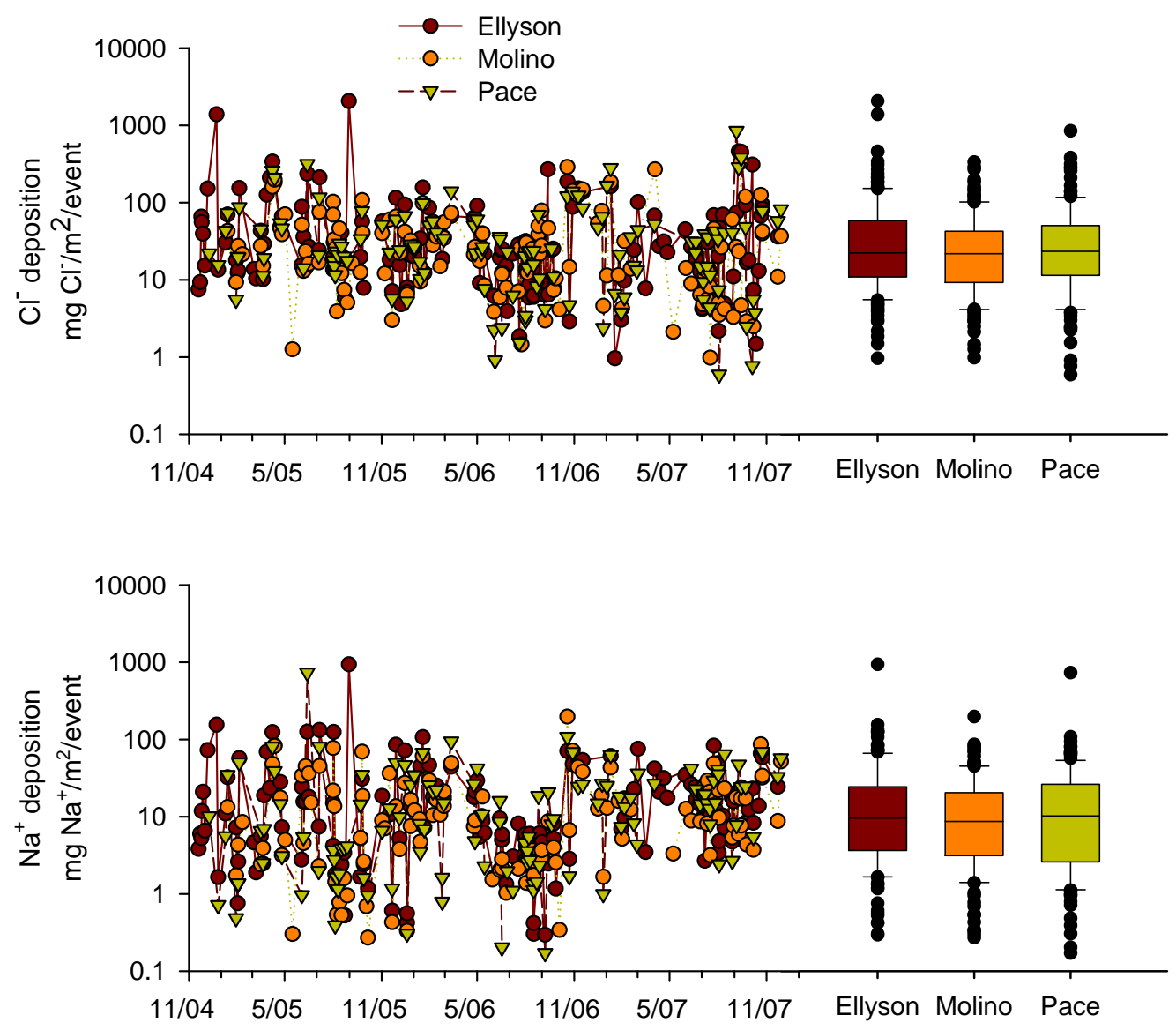

Fig. 5. Chloride $\left(\mathrm{Cl}^{-}\right)$deposition $\left(\mathrm{mg} / \mathrm{m}^{2} /\right.$ event) (top panel) and sodium $\left(\mathrm{Na}^{+}\right)$deposition $\left(\mathrm{mg} / \mathrm{m}^{2} /\right.$ event) (bottom panel) as in Fig. 3 .

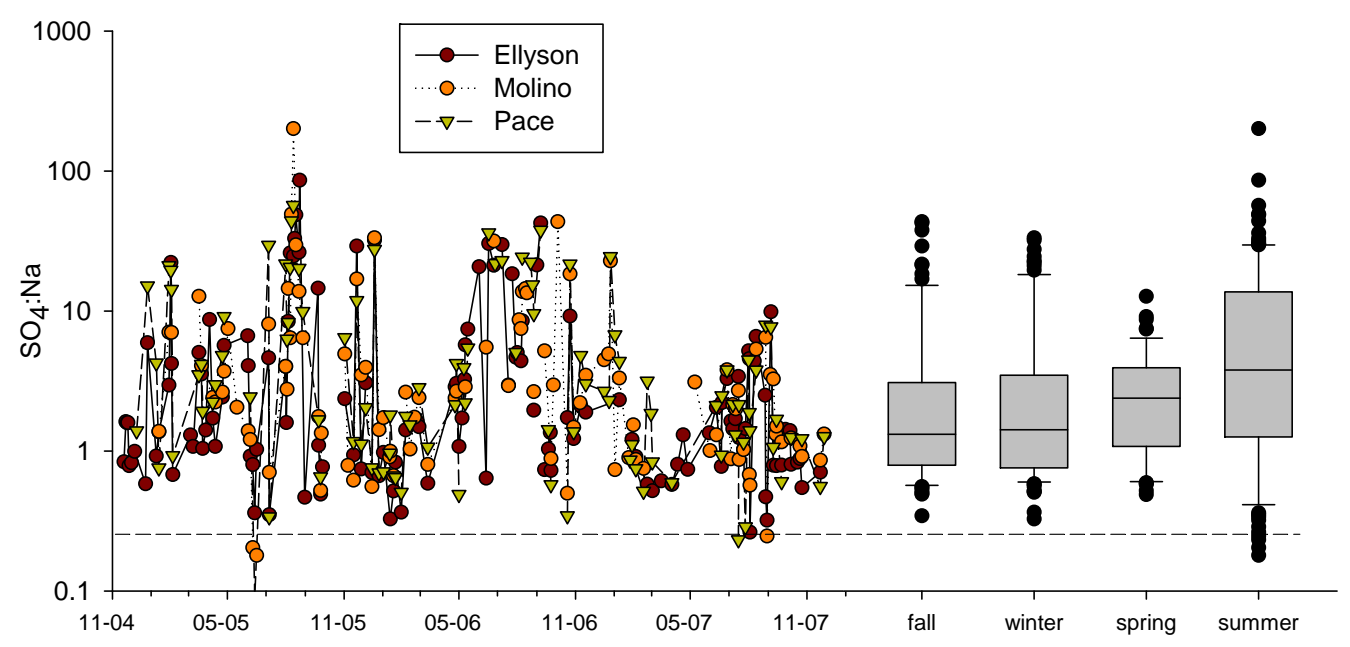

Fig. 6. Plot of the ratio of sulfate $\left(\mathrm{SO}_{4}\right)$ and sodium $(\mathrm{Na})$ deposition at Pensacola Bay sites between November 2004 and December 2007 (left side). The seawater mass ratios $\left(0.25 \mathrm{SO}_{4}: \mathrm{Na}\right)$ is plotted as a dashed line. Box plot (right side) of $\mathrm{SO}_{4}: \mathrm{Na}$ by season. 

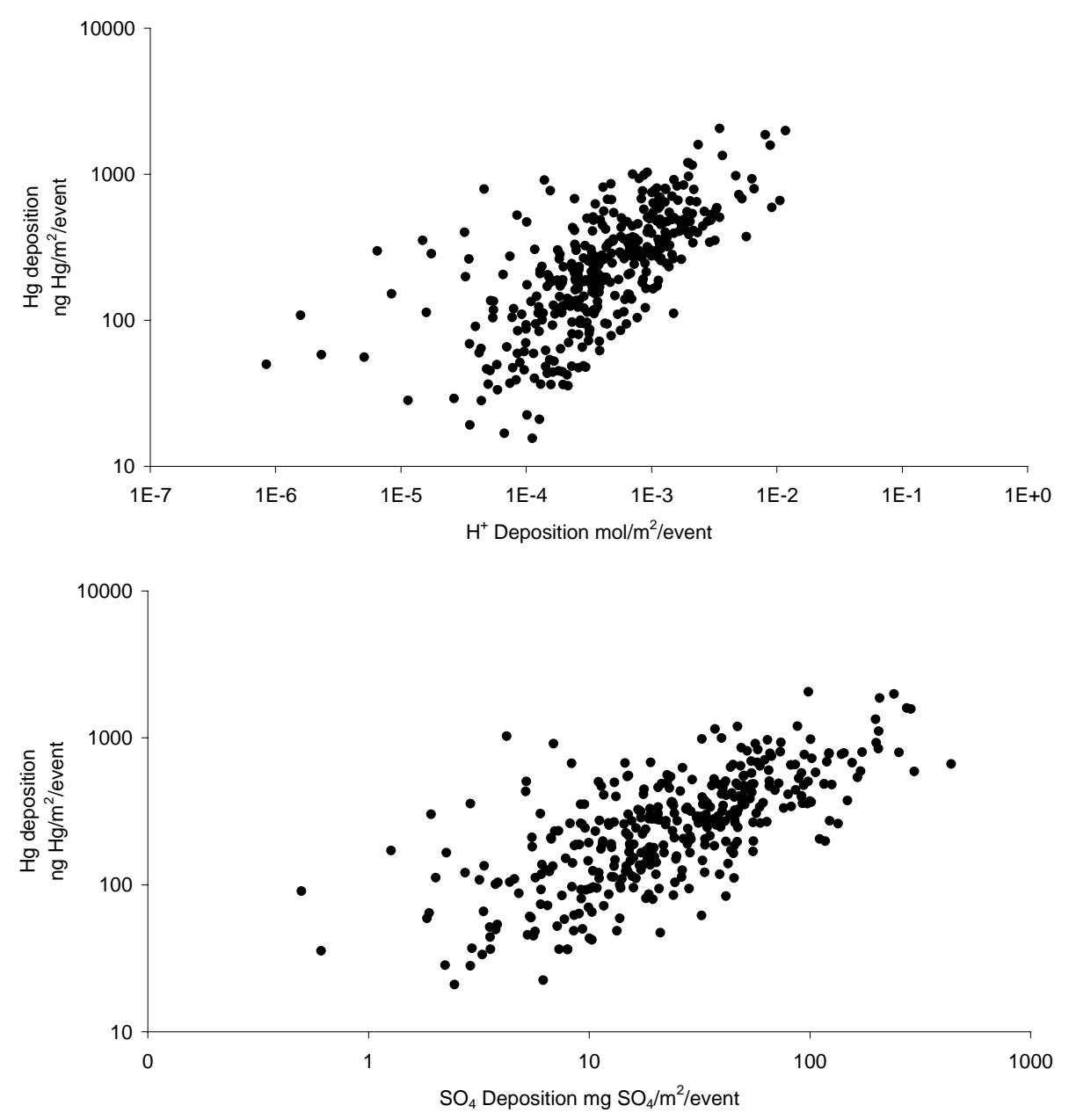

Fig. 7. Plot of $\mathrm{Hg}$ deposition (ng/m²/event) versus $\mathrm{H}^{+}$deposition (mole/ $/ \mathrm{m}^{2} /$ /event) (top panel) and $\mathrm{Hg}$ (ng/m²/event) versus sulfate deposition ( $\mathrm{mg} \mathrm{SO}_{4} / \mathrm{m}^{2} /$ event) (bottom panel).

settings (Elliott et al., 2007; Lohse et al., 2008). In particular, stationary sources are a significant source of $\mathrm{NO}_{\mathrm{x}}$ which results in high nitrate deposition in wet deposition (Elliott et al., 2007). The Florida NADP sites (FL14 and FL23) are much further from urban centers and major pollution sources than either the Alabama NADP or our Pensacola Bay sites. Pensacola Bay sites were not chosen by NADP criteria because we were interested in capturing deposition from local sources. The Molino site is farthest away from pollution sources in Pensacola, about $14 \mathrm{~km}$ from International Paper and $20 \mathrm{~km}$ away from the urban center, yet it still is high for sulfate and nitrate, which are often associated with fossil fuel combustion.

Sea salt aerosols are important in sequestering reactive gaseous and particulate mercury in the Gulf Coast (Engle et al., 2008). In this study, mercury deposition was significantly correlated with sodium deposition, however, the correlation coefficient was quite low $(r=0.22, p=0.02)$. Sea salt aerosols have a significant impact on chemistry of rain water in the Pensacola Bay area. Sodium and chloride, elements associated with sea water, were highly correlated $(r=0.73$, $p<0.001)$. About $21 \%$ of the rainfall events had $\mathrm{Cl}$ :Na ratios near the seawater $\mathrm{Cl}$ :Na ratio of 1.79 . However, chloride deposition were enriched relative to the seawater ratio in about $63 \%$ of the rain events, suggesting that there is another source of chloride in rainwater. The distance of the sampling site to the Gulf of Mexico determines how significant an effect the sea salt aerosols have on rain water composition. Sites that are further from the Gulf have lower average annual sodium deposition than those near to it (data not shown). There was a similar pattern for chloride deposition (data not shown). Fifty $\mathrm{km}$ was the distance where the line becomes asymptotic and the sea salt effect is lost.

Element ratios are a useful tool for examining potential sources in rain water. Our samples were highly enriched in some constituents relative to sodium. The sulfate to sodium ratio was 4 to 100 times greater than seawater ratio (Fig. 6). Only $2 \%$ of the rain events had sulfate:sodium ratios near the 
seawater ratio. The highest ratios generally occurred in the summer, particularly in 2005 (Fig. 6). Several of the major ions associated with acid rain constituents were significantly correlated with one another. Sulfate was strongly correlated with $\mathrm{H}^{+}$and chloride, with correlation coefficients of 0.62 and 0.72 , respectively $(p<0.001)$. The relationships between sulfate and nitrate or ammonium were also significant, but only had correlation coefficients of 0.24 and 0.32 , respectively. The ratio of nitrate to non-sea salt sulfate in our samples was about 0.5 , which is similar to that found during the FAMS study (Landing et al., 1995). Mercury was significantly correlated with $\mathrm{H}^{+}$and sulfate deposition (Fig. 7), with correlation coefficients of 0.6 and 0.73 , respectively $(p<0.001)$. This is similar to the findings from Michigan and the Ohio valley which also observed strong associations between sulfate, $\mathrm{pH}$ and mercury deposition (Landis et al., 2002; Keeler et al., 2006). These relationships are consistent with mercury sources from coal combustion.

The three years of data from this study have shown consistent seasonal trends in mercury and major ion deposition. Because sampling is ongoing at these sites, future papers will be able to address the factors controlling interannual variability and long term trends, particularly the effect of installing scrubbers at Plant Crist.

\section{Conclusions}

In contrast to studies from other regions, mercury deposition at urban sites in the Pensacola Bay watershed was similar to mercury deposition at Mercury Deposition Network sites along the Gulf Coast. However, deposition of acid rain constituents such as $\mathrm{H}^{+}$, sulfate, nitrate, chloride and ammonium was much higher at Pensacola Bay sites than rural National Atmospheric Deposition Network sites along the Gulf Coast. Summer deposition of mercury represented approximately $40 \%$ of the annual deposition, but only $33 \%$ of the annual rainfall.

Acknowledgements. This study was a component of the "Assessment of Environmental Pollution and Community Health in Northwest Florida", supported by a US EPA Cooperative Agreement award X-9745502 to the University of West Florida (Project Director: K. Ranga Rao). We thank Fran Aftanas, Nathaniel Davila, Autumn Dunn, Elizabeth Gaige, Brad Kuykendall, Tanner Martin, Melissa Overton, and Pam Vaughan for their assistance in field collections. We thank Jan Macauley, Jeremy Bosso and the Wetland Research Laboratory for laboratory analyses. The Florida Department of Environmental Protection, Pace Water Systems, and Carol Hatcher provided access to sampling sites. We thank Jessie Brown for her assistance with the database development.

Edited by: R. Ebinghaus

\section{References}

Butler, T. J., Cohen, M. D., Vermeylen, F. M., Likens, G. E., Schmeltz, D., and Artz, R. S.: Regional precipitation mercury trends in the eastern USA, 1998-2005: Declines in the Northeast and Midwest, no trend in the Southeast, Atmos. Environ., 42, 1582-1592, 2008.

Chang, M. E., Baumann, K., Bostrom, A., and Russell, A.: PERCH Air Quality Study: an assessment of particulate matter, ozone, and air toxics in Escambia and Santa Rosa Counties. Final Report, Partnership for Community Health and Environmental Research, available at: $\{$ http://cure.eas.gatech.edu/ chang/perch/\}, 2007.

Dvonch, J. T., Graney, J. R., Marsik, F. J., Keeler, G. J., and Stevens, R. K.: An investigation of source-receptor relationships for mercury in south Florida using event precipitation data, Sci. Total Environ., 213, 95-108, 1998.

Elliott, E. M., Kendall, C., Wankel, S. D., Burns, D. A., Boyer, E. W., Harlin, K., Bain, D. J., and Butler, T. J.: Nitrogen isotopes as indicators of $\mathrm{NO}_{\mathrm{x}}$ source contributions to atmospheric nitrate deposition across the Midwestern and northeastern United States, Environ. Sci. Technol., 41, 7661-7667, 2007.

Engle, M. A., Tate, M. T., Krabbenhoft, D. P., Kolker, A., Olsen, M. L., Edgerton, E. S., DeWild, J. F., and McPherson, A. K.: Characterization and cycling of atmospheric mercury along the central US Gulf Coast, Appl. Geochem., 23, 419-437, 2008.

Guentzel, J. L., Landing, W. M., Gill, G. A., and Pollman, C. D.: Atmospheric deposition of mercury in Florida: the FAMS project (1992-1994), Water Air Soil Poll., 80, 393-402, 1995.

Keeler, G. J. and Dvonch, J. T.: Chapter 25, Atmospheric mercury: a decade of observations in the Great Lakes, in: Dynamics of mercury pollution on regional and global scales: atmospheric processes and human exposures around the world, edited by: Pirrone, N. and Mahaffey, K. R., Springer, 611-636, 2005.

Keeler, G. J., Landis, M. S., Norris, G. A., Christianson, E. M., and Dvonch, J. T.: Sources of mercury wet deposition in Eastern Ohio, USA, Environ. Sci. Technol., 40, 5874-5881, 2006.

Landing, W. M., Perry, J. J. Jr., Guentzel, J. L., Gill, G. A., and Pollman, C. D.: Relationships between atmospheric deposition of trace elements, major ions and mercury in Florida: The FAMS project (1992-1993), Water Air Soil Poll., 80, 343-352, 1995.

Landing, W. M., Caffrey, J. M., Nolek, S. D., Gosnell, K. J., and Parker, W. C.: Atmospheric wet deposition of mercury and other trace elements in Pensacola, Florida, Atmos. Chem. Phys., 10, 4867-4877, doi:10.5194/acp-10-4867-2010, 2010.

Landis, M. S., Vette, A. F., and Keeler, G. J.: Atmospheric mercury in the Lake Michigan Basin: Influence of the Chicago/Gary Urban Area, Environ. Sci. Technol., 36, 4508-4517, 2002.

Lawson, N. M. and Mason, R. P.: Concentration of mercury, methylmercury, cadmium, lead, arsenic and selenium in the rain and stream water of two contrasting watersheds in western Maryland, Water Res., 35, 4039-4052, 2001.

Lin, C.-J. and Pehkonen, S.O.: The chemistry of atmospheric mercury: a review, Atmos. Environ., 33, 2067-2079, 1999.

Lindberg, S., Bullock, R., Ebinghaus, R., Engstrom, D., Feng, X., Fitzgerald, W., Pirrone, N., Prestbo, E., and Seigneur, C.: A synthesis of progress and uncertainties in attributing the sources of mercury in deposition, Ambio, 36, 19-32, 2007.

Lindqvist, O. and Rodhe, H.: Atmospheric mercury - a review, Tellus, 37, 136-159, 1985. 
Lohse, K. A., Hope, D., Sponsell, R.,. Allen, J. O., and Grimm, N. B.: Atmospheric deposition of carbon and nutrients across an arid metropolitan area, Sci. Total Environ., 402, 95-105, 2008.

Lynch, J. A. and Kerchner, M.: The National Atmospheric Deposition Program: 25 years of monitoring in support of science and policy: an ammonia workshop: the state of science and future needs, Environ. Pollut., 135, 343-346, 2005.

Mason, R. P, Lawson, N. M., and Sullivan, K. A.: The concentration, speciation and sources of mercury in Chesapeake Bay precipitation, Atmos. Environ., 31, 3541-3550, 1997.

Mason, R. P, Lawson, N. M., and Sheu, G. R.: Annual and seasonal trends in mercury deposition in Maryland, Atmos. Environ., 34, 1691-1701, 2000.

National Atmospheric Deposition Program (NRSP-3)/National Trends Network, NADP Program Office, Illinois State Water Survey, 2204 Griffith Drive, Champaign, IL 61820, 2009.

Pacyna, J. M., Munthe, J., Larjava, K., and Pacyna, E. G.: Chapter 3. Mercury emissions from anthropogenic sources: estimates and measurements for Europe, in: Dynamics of mercury pollution on regional and global scales: atmospheric processes and human exposures around the world, edited by: Pirrone, N. and Mahaffey, K. R., Springer, 51-64, 2005.
Pirrone, N., Keeler, G. J., and Nriagu, J. O.: Regional differences in worldwide emissions of mercury to the atmosphere, Atmos. Environ., 30, 2981-2987, 1996.

Valigura, R. A.: An introduction to the first assessment of nitrogen loads to US estuaries with an atmospheric perspective, in: Nitrogen loading in coastal water bodies: an atmospheric perspective, edited by: Valigura, R. A., Alexander, R. B., Castro, M. S., Meyers, T. P., Paerl, H. W., Stacey, P. E., and Turner, R. E. , AGU, Washington, DC, 1-10, 2001.

VanArsdale, A., Weiss, J., Keeler, G., Miller, E., Boulet, G., Brulotte, R., and L. Poissant.: Patterns of mercury deposition and concentration in Northeastern North America (1996-2002), Ecotoxicology, 14, 37-52, 2007.

White, E. M., Keeler, G. J., and Landis, M. S.: Spatial variability of mercury wet deposition in Eastern Ohio: Summertime meteorological case study analysis of local source influences, Environ. Sci. Technol., 43, 4946-4953, 2009. 